\title{
The cadmium-phosphate relationship in brine: biological versus physical control over micronutrients in sea ice environments
}

\author{
KATHARINE R. HENDRY ${ }^{1 *}$, ROSALIND E.M. RICKABY ${ }^{1}$, JAN C.M. DE HOOG ${ }^{1}$, KEITH WESTON ${ }^{2}$ and \\ MARK REHKAMPER ${ }^{3}$ \\ ${ }^{1}$ Department of Earth Sciences, University of Oxford, Parks Road, Oxford OX1 3PR, UK \\ ${ }^{2}$ Laboratory for Global Marine and Atmospheric Chemistry, School of Environmental Sciences, University of East Anglia, \\ Norwich NR4 7TJ, UK \\ ${ }^{3}$ Department of Earth Sciences and Engineering, Imperial College, London SW7 2AZ, UK \\ *kathh@earth.ox.ac.uk
}

\begin{abstract}
Despite supporting productive ecosystems in the high latitudes, the relationship between macroand micronutrients in sea ice environments and their impact on surface productivity is poorly documented. In seawater, the macronutrient phosphate and the micronutrient cadmium follow similar distributions, which are controlled by biological processes in surface waters. We investigated cadmium and phosphate in sea ice brine, and the biological and physical processes controlling their distribution. Cadmium concentrations in sea ice brine ranged from $0.09-2.4 \mathrm{nmol} \mathrm{kg}^{-1}$, and correlated well with salinity. Our results show that micronutrients in sea ice are most probably sourced from the seawater from which it froze rather than external sources such as atmospheric deposition. The weak correlation between sea ice cadmium and phosphate, and the positive relationship between cadmium and biomass, suggests against biological uptake being a principal control over micronutrient distribution even in a highly productive setting. Instead, brine expulsion and dilution play a dominant role in cadmium distribution in sea ice. Nutrient dilution within brine channels during melting, and contrasting sea ice and open water phytoplankton populations, suggests that late spring sea ice is not a significant source of nutrients or biomass to seawater. We suggest that future changes in sea ice seasonality may impact nutrient distribution and Antarctic marine ecosystems.
\end{abstract}

Received 22 May 2009, accepted 21 July 2009

Key words: Antarctica coastal waters, biogeochemistry, nutrients, trace elements

\section{Introduction}

Sea ice plays a vital role in global climate systems, influencing the exchange of heat and atmospheric gases (including carbon dioxide, $\mathrm{CO}_{2}$ ), deepwater formation, regional weather patterns, planetary albedo and ocean circulation (Stephens \& Keeling 2000, Parkinson 2004). Biological primary productivity associated with Antarctic sea ice significantly impacts the global cycling of carbon, contributing to an estimated 10-28\% of Southern Ocean production (Abelmann \& Gersonde 1991, Lizotte 2001, Arrigo \& Thomas 2004), as well as the availability of macro- and micronutrients (Sedwick \& Di Tullio 1997). Sea ice algae may contribute significantly to the sinking of organic matter from surface waters to the seafloor (export production), due to flocculation, high silica content and repackaging in faecal pellets of small grazers such as copepods (Cadée et al. 1992, Shimmield et al. 1995, Nelson et al. 2002, Brierley \& Thomas 2002). This rapid export of organic matter associated with sea ice reduces the time available for remineralization and, consequently, sea ice organic carbon burial may be a significant sink for atmospheric $\mathrm{CO}_{2}$ (Abelmann et al. 2006).

Sea ice is a unique biological habitat that experiences extreme physical and chemical conditions. For example, nutrient levels within sea ice show a high degree of spatial heterogeneity, and depend on physical factors, such as ice formation, consolidation and ablation (Thomas et al. 1998), and biological factors including community structure and bacterial activity (Kottmeier \& Sullivan 1990). The nutrients may be sourced internally (e.g. bacterial activity, Kottmeier \& Sullivan 1990) or externally from ice sheets or vertical eddy diffusion from underlying waters (Cota \& Sullivan 1990, Lizotte 2001). The prevalence of nitrifying bacteria, regeneration of nutrients in a closed or semiclosed system and physical processes, results in elevated nitrite, dissolved organic matter, ammonium and phosphate (Clarke \& Ackley 1984, Dieckmann et al. 1991, 1992, Thomas et al. 2001). Nutrient limitation may occur in sea ice (McConville et al. 1985, Dieckmann et al. 1991) although sea ice algae appear to have physiological adaptations and a sufficiently strong affinity for some nutrients, e.g. Si, to avoid limitation (Nelson \& Tréguer 1992, Stapleford \& Smith 1996, McMinn et al. 1999).

For over 20 years, it has been known that cadmium $(\mathrm{Cd})$ exhibits a similar distribution to Dissolved Inorganic Phosphate (DIP or $\mathrm{PO}_{4}{ }^{3-}$ ) in seawater (reviewed by de Baar 1994, Elderfield \& Rickaby 2000). The nature of this relationship, however, remains elusive, although there is 


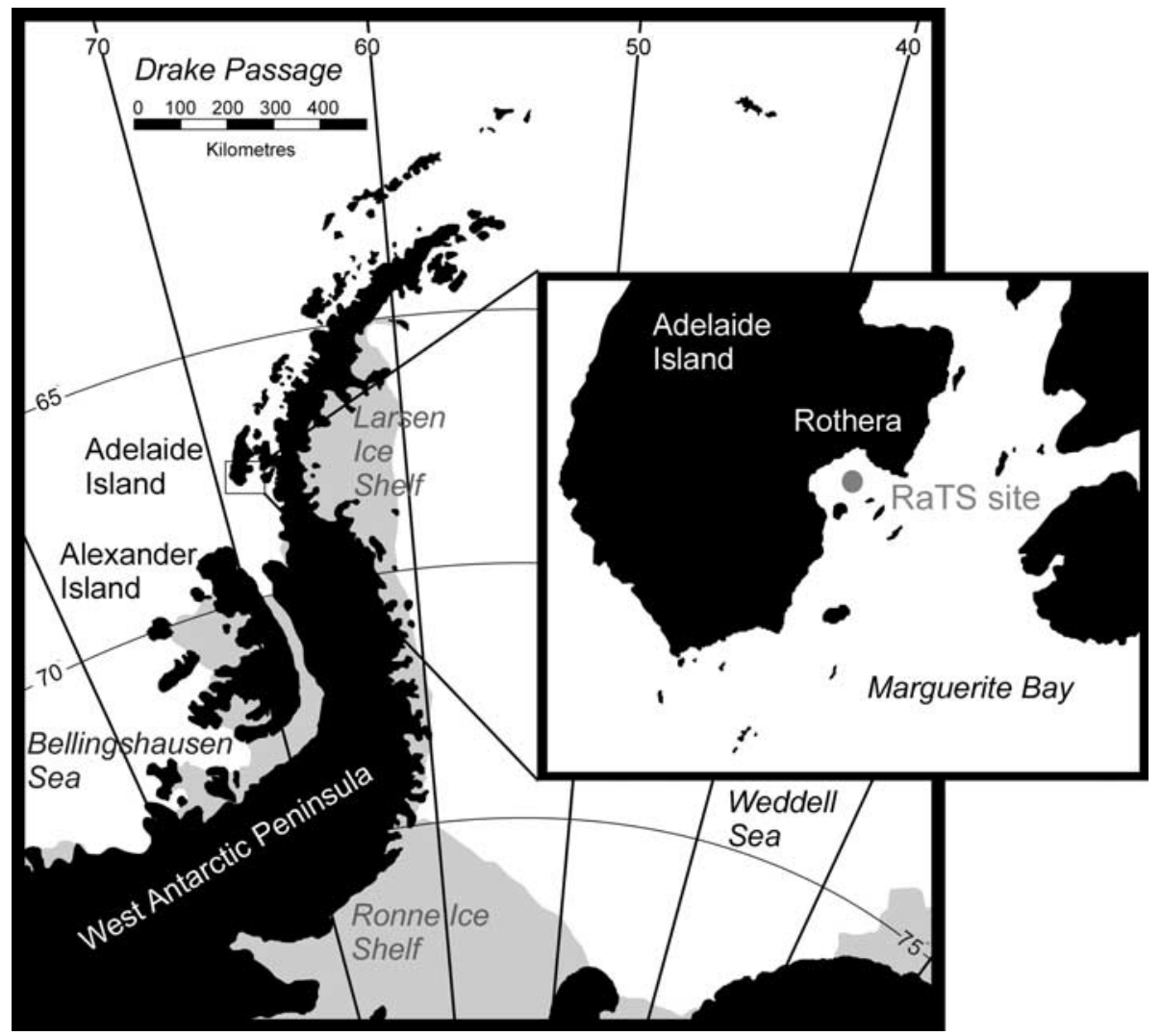

Fig. 1. A map of the study area showing Marguerite Bay sampling region. Samples were taken from near Rothera Research Station and from the Rothera Oceanographic and Biological Time-Series (RaTS) sampling site.

increasing evidence that $\mathrm{Cd}$ is a micronutrient actively taken up by phytoplankton, rather than being passively scavenged onto organic matter. Recent molecular work has shown the existence of a specific Cd metalloenzyme, Cdcarbonic anhydrase (Cd-CA), required for photosynthesis by phytoplankton (Lane \& Morel 2000b, Xu et al. 2008). Further, Cd isotopic fractionation in surface water is highly indicative of biological uptake (Ripperger et al. 2007).

The departure from the quasi-linear relationship between $\mathrm{Cd}$ and $\mathrm{PO}_{4}{ }^{3-}$ (de Baar 1994) in surface waters is also poorly understood, and may result from fractionation of $\mathrm{Cd}$ with respect to $\mathrm{P}$ into organic matter (Elderfield \& Rickaby 2000), growth rate effects, population structure (Finkel et al. 2007), interactions with other trace metals (Fe, Zn), variations in $\mathrm{pCO}_{2}$ and carbonic anhydrase activity (Cullen \& Sherrell 2005, Cullen 2006, Hendry et al. 2008).

Although there is some limited data on macronutrients, there is currently no data on Cd concentrations in sea ice brine to act as a direct comparison to open water conditions. Here, we present $\mathrm{Cd}$ data from sea ice brine collected by sackhole drilling and analysed by ICP-MS using isotope dilution followed by magnesium hydroxide precipitation of filtered samples. Our results show that physical processes are probably as important, if not more so, than biological processes in controlling the distribution of micronutrients in the sea ice environment. In the light of these results, we discuss the probable impact of sea ice melt on the surrounding seawater.

\section{Methods and materials}

Sea ice brine sampling was carried out in Marguerite Bay, Adelaide Island, from June 2005 to December 2006 in collaboration with the British Antarctic Survey Rothera Oceanographic and Biological Time-Series (RaTS; Fig. 1). The study site is described fully elsewhere (Clarke et al. 2008, Meredith et al. 2008).

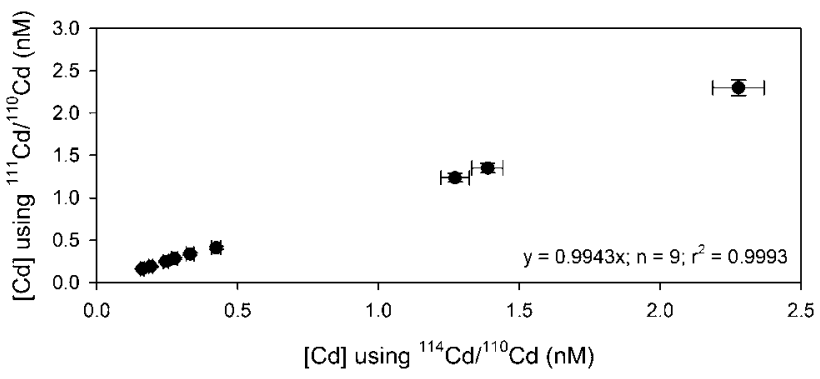

Fig. 2. Comparison of sample concentrations calculated using ${ }^{111} \mathrm{Cd} /{ }^{110} \mathrm{Cd}$ and ${ }^{114} \mathrm{Cd} /{ }^{110} \mathrm{Cd}$. Error bars show $\pm 1 \sigma$. 
Table I. Collection day, temperature, biomass, macro- and miconutrient results for sea ice brines. All macro- and micronutrient data were corrected for density and reported per kg (a maximum correction of approximately 5\%), which was calculated from brine or underlying water temperatures and brine salinity calculated from Na concentrations, using CSGNetwork Water Density Calculator version 1.6.4. (http://www.csgnetwork.com/h2odenscalc.html).

\begin{tabular}{|c|c|c|c|c|c|c|c|c|c|c|c|c|c|c|c|}
\hline Date & $\begin{array}{l}\text { Temp } \\
\left({ }^{\circ} \mathrm{C}\right)\end{array}$ & $\begin{array}{c}\text { Total } \\
\text { chl } a \\
\left(\mathrm{mg} \mathrm{m}^{-3}\right)\end{array}$ & $\begin{array}{c}\mathrm{Si}(\mathrm{OH})_{4} \\
\left(\mu \mathrm{mol} \mathrm{l}^{-1}\right)\end{array}$ & $\begin{array}{c}\mathrm{NO}_{3}^{-} \\
\left(\mu \mathrm{mol} \mathrm{l}{ }^{-1}\right)\end{array}$ & $\begin{array}{c}\mathrm{PO}_{4}^{3-} \\
\left(\mu \mathrm{mol} \mathrm{l} l^{-1}\right)\end{array}$ & $\begin{array}{c}\mathrm{Cd} \\
\left(\mathrm{nmol} \mathrm{l}^{-1}\right) \\
\mathrm{SA}^{\mathrm{a}}\end{array}$ & $\begin{array}{c}\mathrm{Cd} \\
\left(\mathrm{nmol} \mathrm{l}^{-1}\right) \\
\mathrm{ID}^{\mathrm{b}}\end{array}$ & $\begin{array}{c}\mathrm{Na} \\
\left(\mathrm{mmol} \mathrm{kg}^{-1}\right)\end{array}$ & $\begin{array}{l}\text { Calculated } \\
\text { salinity }\end{array}$ & $\begin{array}{c}\text { Density } \\
\left(\mathrm{g} \mathrm{l}^{-1}\right)\end{array}$ & $\begin{array}{c}\mathrm{Si}(\mathrm{OH})_{4} \\
\left(\mu \mathrm{mol} \mathrm{kg}{ }^{-1}\right)\end{array}$ & $\begin{array}{c}\mathrm{NO}_{3}^{-} \\
\left(\mu \mathrm{mol} \mathrm{kg}{ }^{-1}\right)\end{array}$ & $\begin{array}{c}\mathrm{PO}_{4}^{3-} \\
\left(\mu \mathrm{mol} \mathrm{kg}{ }^{-1}\right)\end{array}$ & $\begin{array}{c}\mathrm{Cd} \\
\left(\mathrm{nmol} \mathrm{kg}^{-1}\right) \\
\mathrm{SA}^{\mathrm{a}}\end{array}$ & $\begin{array}{c}\mathrm{Cd} \\
\left(\mathrm{nmol} \mathrm{kg}^{-1}\right) \\
\mathrm{ID}^{\mathrm{b}}\end{array}$ \\
\hline $17 / 09 / 05$ & & 4.53 & 95.8 & 13.5 & 0.4 & 0.891 & & 1095 & 63.5 & 1052 & 91.1 & 12.8 & 0.4 & 0.85 & \\
\hline $13 / 10 / 05$ & & 0.64 & 30.0 & 1.7 & 0.3 & 0.222 & & 233 & 13.5 & 1011 & 29.7 & 1.7 & 0.3 & 0.22 & \\
\hline $21 / 11 / 05$ & -3.8 & 2.76 & 22.0 & 2.1 & 0.4 & 0.414 & & 347 & 20.1 & 1016 & 21.6 & 2.1 & 0.4 & 0.41 & \\
\hline $23 / 11 / 05$ & -1.5 & 1.66 & 11.7 & 9.1 & 0.2 & 0.765 & & 340 & 19.7 & 1016 & 11.5 & 8.9 & 0.2 & 0.75 & \\
\hline $28 / 11 / 05$ & -2.7 & 1.33 & & & & 0.216 & & 182 & 10.6 & 1008 & & & & 0.21 & \\
\hline $01 / 12 / 05$ & -2.0 & & & 3.8 & 0.6 & 0.284 & & 191 & 11.1 & 1009 & & 3.8 & 0.6 & 0.28 & \\
\hline $06 / 12 / 05$ & -1.8 & 1.17 & & 1.1 & 0.3 & 0.290 & & 185 & 10.7 & 1008 & & 1.0 & 0.3 & 0.29 & \\
\hline 09/12/05 & -0.9 & 0.91 & 4.0 & 1.0 & 0.2 & 0.250 & & 196 & 11.4 & 1009 & 3.9 & 1.0 & 0.2 & 0.25 & \\
\hline $20 / 12 / 05$ & -1.1 & 1.77 & 6.3 & 1.1 & 0.3 & 0.162 & & 146 & 8.5 & 1007 & 6.3 & 1.1 & 0.3 & 0.16 & \\
\hline $31 / 07 / 06$ & $-1.8^{*}$ & 0.65 & 113.1 & 72.5 & 3.2 & 1.524 & 1.25 & 842 & 48.8 & 1039 & 108.8 & 69.8 & 3.1 & 1.47 & 1.25 \\
\hline $22 / 08 / 06$ & & & 156.2 & 129.6 & 7.2 & 2.268 & & 1506 & 87.3 & 1071 & 145.8 & 121.0 & 6.7 & 2.12 & \\
\hline $31 / 08 / 06$ & $-1.8^{*}$ & 1.04 & 131.0 & 111.0 & 3.0 & 2.562 & 2.11 & 1314 & 76.2 & 1062 & 123.4 & 104.5 & 2.8 & 2.41 & 2.11 \\
\hline $18 / 09 / 06$ & $-1.8^{*}$ & 0.50 & 50.8 & 21.8 & 2.1 & 0.248 & 0.27 & 157 & 9.1 & 1007 & 50.5 & 21.7 & 2.1 & 0.25 & 0.27 \\
\hline $27 / 09 / 06$ & $-1.8^{*}$ & 1.26 & 143.0 & 108.4 & 3.2 & 1.778 & 1.39 & 1139 & 66.1 & 1054 & 135.7 & 102.9 & 3.1 & 1.69 & 1.39 \\
\hline 09/10/06 & $-1.7^{*}$ & 8.77 & 121.9 & 13.3 & 0.6 & 0.369 & & 673 & 39.0 & 1031 & 118.2 & 12.9 & 0.6 & 0.36 & \\
\hline $02 / 11 / 06$ & & 2.31 & 13.3 & 3.3 & 0.1 & 0.060 & & 63 & 3.6 & 1003 & 13.3 & 3.3 & 0.1 & 0.06 & \\
\hline $03 / 11 / 06$ & $-1.4^{*}$ & 0.97 & 15.9 & 1.7 & 0.1 & 0.117 & 0.19 & 52 & 3.0 & 1002 & 15.8 & 1.7 & 0.1 & 0.12 & 0.19 \\
\hline 09/11/06 & $-1.3^{*}$ & 0.46 & 26.6 & 1.9 & 0.2 & 0.205 & 0.24 & 132 & 7.6 & 1006 & 26.4 & 1.9 & 0.2 & 0.20 & 0.24 \\
\hline $10 / 11 / 06$ & $-1.3 *$ & 1.41 & 32.7 & 0.1 & 0.3 & 0.216 & 0.16 & 168 & 9.7 & 1008 & 32.5 & 0.1 & 0.3 & 0.21 & 0.16 \\
\hline $15 / 11 / 06$ & $-1.4^{*}$ & 0.70 & 22.3 & 1.9 & 0.7 & 0.274 & 0.03 & 116 & 6.7 & 1005 & 22.2 & 1.9 & 0.7 & 0.27 & 0.33 \\
\hline $21 / 11 / 06$ & $-1.4^{*}$ & 0.80 & 39.4 & 2.2 & 0.2 & 0.506 & 0.41 & 244 & 14.1 & 1011 & 38.9 & 2.1 & 0.2 & 0.50 & 0.41 \\
\hline $02 / 12 / 06$ & $-1.4^{*}$ & 1.33 & 18.1 & 0.7 & & 0.210 & & 165 & 9.59 & 1001 & 18.1 & 0.7 & & 0.21 & \\
\hline $07 / 12 / 06$ & 0.5 & 0.41 & 15.4 & & 0.1 & 0.060 & & 115 & 6.6 & 1000 & 15.4 & & 0.1 & 0.06 & \\
\hline
\end{tabular}

*Temperature data are only available for underlying seawater. If no temperature data are available, temperature was estimated from previous value.

${ }^{\text {a }}$ Cadmium concentrations measured using Standard Addition (SA).

${ }^{\mathrm{b}}$ Cadmium concentrations measured using co-precipitation followed by Isotope Dilution (ID) 
The brine was collected using sackhole drilling. Snow was removed from the surface of the sea ice, and the sea ice surface cleaned with a plastic edge. Partial holes were drilled into the sea ice, ensuring not to penetrate the waterice interface, scraped with a plastic edge and covered for five minutes to one hour. The brine drained into the holes and was collected into clean HDPE containers. Water samples were collected from below sea ice near Rothera Research Station into clean containers. Chlorophyll $a(\mathrm{chl} a)$ was determined by extracting pigments from filtered subsamples using chloroform/methanol, before analysis by fluorometry (Clarke et al. 2008). However, it should be noted that sackhole drilling is not suitable for accurate determination of particulate concentrations, so the chl $a$ concentrations are only an approximate measure of biomass (Weissenberger 1992). The brine and water were filtered under clean conditions in the Bonner Laboratories, Rothera Research Station using 0.2 micrometer polycarbonate membranes (Whatman). The filtrate was acidified using $1 \mathrm{ml}$ sub-boiling distilled $\mathrm{HNO}_{3}$ per litre of brine and transported back to the UK for analysis. All plasticware and filter membranes were trace metal clean. Additional samples were filtered for silicic acid $\left(\mathrm{Si}(\mathrm{OH})_{4}\right)$ and $\mathrm{PO}_{4}{ }^{3-}$ analysis. Glass fibre filters (Whatman $\mathrm{GF} / \mathrm{F}$ ) are routinely used to filter seawater for $\mathrm{NO}_{3}{ }^{-}$and $\mathrm{PO}_{4}{ }^{3-}$ analysis. Silica free polycarbonate $0.2 \mu \mathrm{m}$ filter membranes (Whatman) were used to filter seawater for $\mathrm{Si}(\mathrm{OH})_{4}$ analysis to avoid contamination by any Si released from the glass fibres of the GF/F membranes.

Approximate $\mathrm{Cd}$ concentrations were measured initially on a Perkin Elmer Elan 6100DRC Quadrupole Inductively Coupled Plasma Mass Spectrometer (Q-ICP-MS) using a standard addition method based on a protocol for analysing trace metals $(\sim \mathrm{ppb})$ in high matrix solutions (Hendry et al. 2008). Laboratory blanks of Milli-Q water were measured by standard addition and were found to be below detection level $(\sim 1 \mathrm{ppt})$. Brine sodium concentrations were also measured using Q-ICP-MS measured against an In internal standard. Internal reproducibility using the In standard is excellent $(<0.1 \%)$ and external reproducibility was estimated at between 0.05 and $1.12 \%$ using repeat dilutions.

Precise and accurate $\mathrm{Cd}$ concentrations were then measured using an isotope dilution method, followed by magnesium hydroxide co-precipitation (Wu \& Boyle 1997, Ripperger \& Rehkamper 2007, Hendry et al. 2008). Briefly, approximately $13 \mathrm{ml}$ of acidified seawater or brine was weighed in $15 \mathrm{ml}$ polypropylene centrifuge tubes ( 5 point balance $\pm 0.01 \mathrm{mg}$ ), spiked with $400 \mu \mathrm{l}$ enriched ${ }^{110} \mathrm{Cd}$ spike (Ripperger \& Rehkamper 2007). FEP distilled aqueous $\mathrm{NH}_{3}(500-2000 \mu \mathrm{l})$ was added to precipitate $\mathrm{Mg}(\mathrm{OH})_{2}$; the amount added was determined empirically to allow $\sim 7 \% \mathrm{Mg}$ to precipitate to minimize matrix effects during analysis $(\mathrm{Mg} \sim 1000 \mathrm{ppm})$. After the $\mathrm{NH}_{4} \mathrm{OH}$ is added, the sample is left before centrifugation at $6000 \mathrm{rpm}$ for $4 \mathrm{~min}$. For seawater samples this precipitation process took two minutes. However, for sea ice brine, the precipitation process takes longer and the samples are left for 30 minutes prior to centrifugation. The supernatant is discarded and the precipitate is redissolved in $0.5 \mathrm{ml} 5 \%$ $\mathrm{HNO}_{3}$ (sub-boiling quartz-distilled $\mathrm{HNO}_{3}$ in Milli-Q water), diluted with $0.5 \mathrm{ml}$ Milli-Q and analysed for $\mathrm{Cd}$ by ICP-MS. All precipitation processes were carried out under Class 100 clean conditions.

The standards and samples were analysed for Cd isotopes using an Element II ICP-MS (Thermo Finnigan), introduced via a Cetac ASX-100 microautosampler. The full procedure is detailed elsewhere (Hendry et al. 2008). Uncertainties are estimated to be $\sim 3 \%$ using repeat measurements and comparison to external standards (NASS4). Concentrations calculated using ${ }^{111} \mathrm{Cd} /{ }^{110} \mathrm{Cd}$ and ${ }^{114} \mathrm{Cd} /{ }^{110} \mathrm{Cd}$ agree well (Fig. 2). However, a previous study has shown that concentrations calculated using measured ${ }^{114} \mathrm{Cd} /{ }^{110} \mathrm{Cd}$ are more precise and accurate than those from ${ }^{111} \mathrm{Cd} /{ }^{110} \mathrm{Cd}$, and will be quoted here in the results section (Hendry et al. 2008).

$\mathrm{NO}_{3}{ }^{-}, \mathrm{PO}_{4}{ }^{3-}$ and $\mathrm{Si}(\mathrm{OH})_{4}$ were measured on brine samples using a Skalar Auto analyser (Kirkwood 1996). The $\mathrm{PO}_{4}{ }^{3-}$ concentrations have an estimated uncertainty of $5 \%$, and error propagation thus yields an uncertainty of $\sim 5.5 \%$ for the $\mathrm{Cd} / \mathrm{PO}_{4}{ }^{3-}$ ratios. All macro- and micronutrient data (Table I) were corrected for density and reported per kg (a maximum correction of approximately 5\%), which was calculated from brine temperatures and salinities, using CSGNetwork Water Density Calculator version 1.6.4. (http://www.csgnetwork. $\mathrm{com} / \mathrm{h}$ 2odenscalc.html). Where brine temperatures were not recorded, temperatures from the underlying water were used. This introduces minimal uncertainty because salinity is the primary control on density at these low temperatures.

\section{Sampling contamination}

The sampling of brine is far more susceptible to contamination than seawater given the need to use a metal drill to penetrate the sea ice. In December 2006, sequential samples were taken from a sackhole at five minute intervals

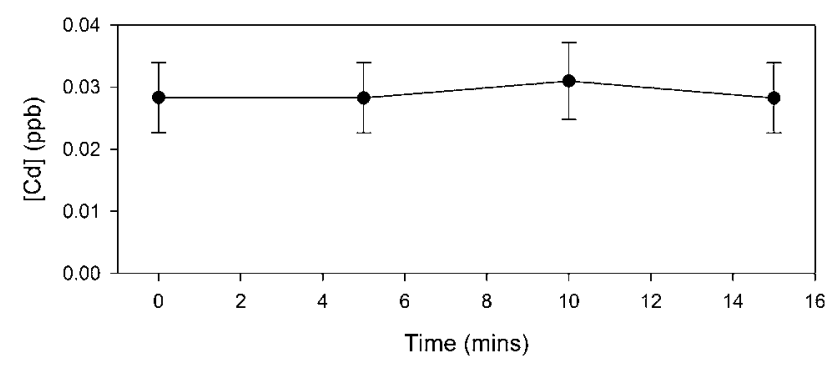

Fig. 3. Results of contamination experiment. Brine samples were taken at time intervals after ice drilling, filtered, acidified and analysed for $\mathrm{Cd}$. There is no decrease in $\mathrm{Cd}$ content through time, suggesting that contamination from the drill is negligible. Error bars show $\pm 2 \sigma$. 


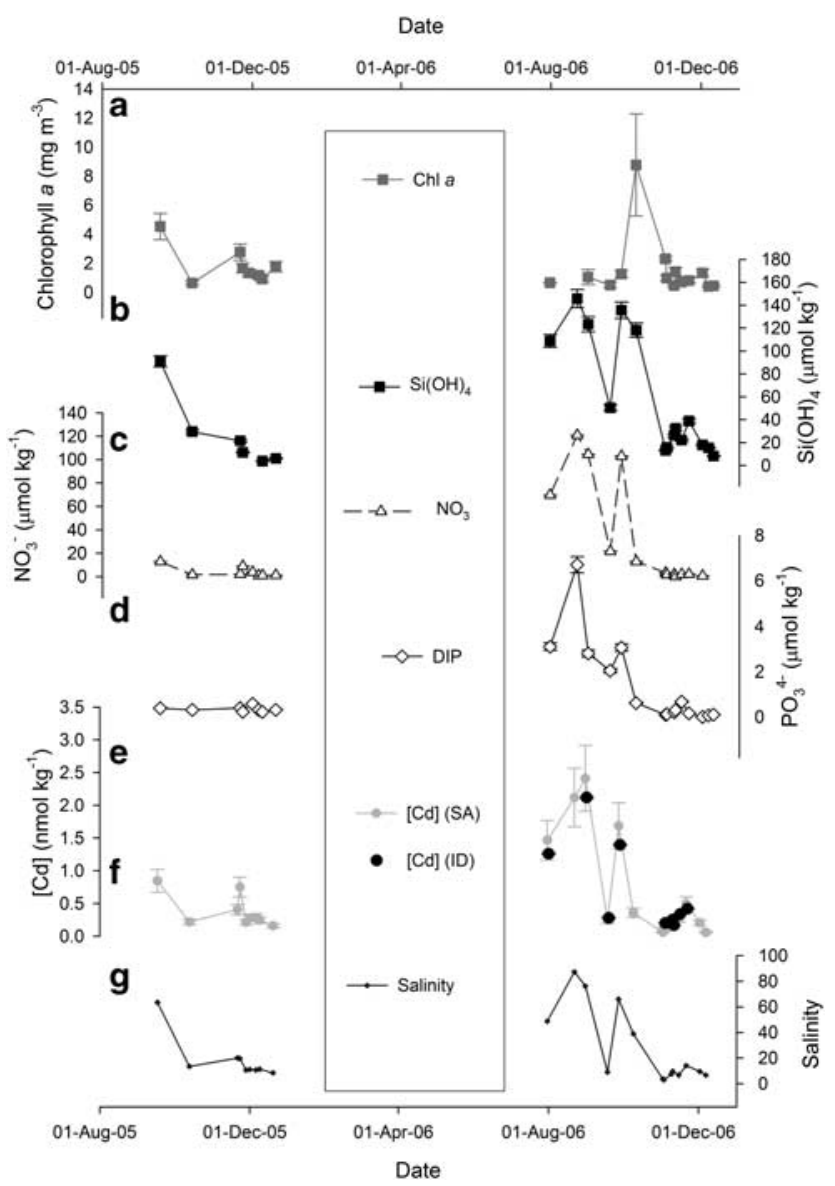

Fig. 4. Macro- and micronutrient results from sea ice brine samples collected by sackhole drilling. a. Total unfractionated chl $a$ (data courtesy of British Antarctic Survey), b. $\mathrm{Si}(\mathrm{OH})_{4}$, c. $\mathrm{NO}_{3}{ }^{-}$, and d. $\mathrm{PO}_{3}{ }^{4-}$ concentrations, f. $\mathrm{Cd}$ concentrations measured by standard addition (light grey circles) and isotope dilution (black circles), and g. salinity, calculated from $\mathrm{Na}$ concentrations measured by Q-ICP-MS. Error bars show $\pm 2 \sigma$.

to show that contamination of brine with $\mathrm{Cd}$ from the drill is negligible (Fig. 3).

\section{Results}

In order to quantify algal activity and trace metal uptake, we report our $\mathrm{Cd}$ results relative to the dilution curve of seawater (Thomas \& Papadimitriou 2003). Salinity, calculated from [Na], decreased during the season as a result of progressive melting from 60 to less than 10. Brines exhibit a wide range of macronutrient concentrations with $\mathrm{Si}(\mathrm{OH})_{4}, \mathrm{NO}_{3}{ }^{-}$and $\mathrm{PO}_{4}{ }^{3-}$ ranging from $<10$ to $150,<1$ to 120 and $<0.1$ to $6.7 \mu \mathrm{mol} \mathrm{kg}^{-1}$ respectively (Fig. 4, Table I). $\mathrm{Cd}$ concentrations varied from $0.06-2.4 \mathrm{nmol} \mathrm{kg}^{-1}$ (Fig. 4, Table I). Cd concentrations in seawater underlying the sea ice near Rothera (winter-spring 2005) are $0.7-0.8 \mathrm{nmol} \mathrm{kg}^{-1}$, and are approximately constant throughout the sampling period.
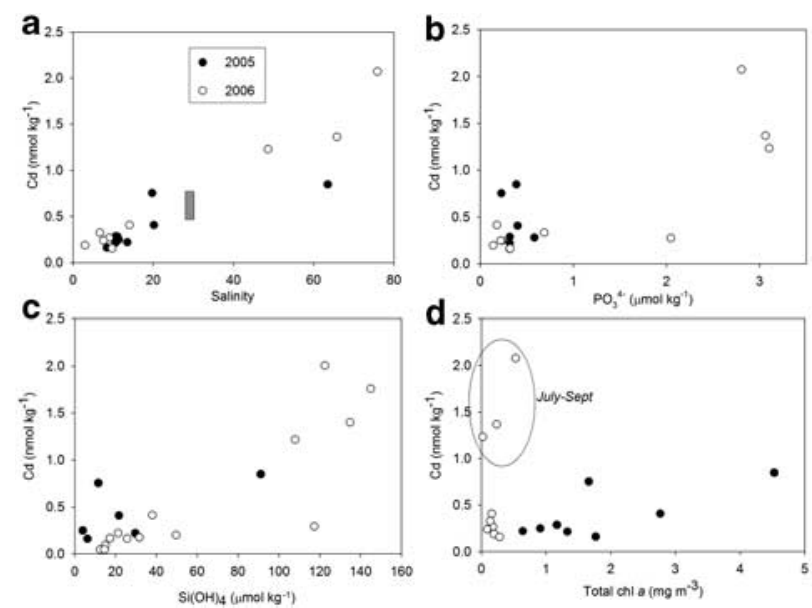

Fig. 5. Correlation between $\mathrm{Cd}$ concentrations and a. salinity (grey bar shows typical seawater composition from Hendry et al. 2008), b. $\mathrm{PO}_{3}{ }^{4-}$, c. $\mathrm{Si}(\mathrm{OH})_{4}$, and d. chl $a$. The early season (July-September) sea ice results are highlighted by the circle. Note the $2005 \mathrm{Cd}$ concentrations were measured only by standard addition; the 2006 samples were also measured by isotope dilution.

\section{Discussion}

Sea ice forms from the freezing of seawater, producing a network of brine channels in a variety of textures (reviewed by Brierley \& Thomas 2002). Marguerite Bay sea ice is a mixture of congelation and granular ice, with a predominance of granular ice as in other regions of Antarctica. The granular ice comprises both snow ice (15\%) and frazil ice and can, thus, be classified as the "warm end member" of Antarctic sea ice (Perovich et al. 2004). As a comparison, Weddell Sea granular ice comprises near $100 \%$ snow ice as a result of rapid snow ice formation at the surface and rapid basal melting as a result of upwelling warm water (Dieckmann et al. 1991). The sea ice in Marguerite Bay can be above the porosity threshold, especially in late winter/spring, resulting in rapid flushing and early algal growth (Perovich et al. 2004). Sea ice brine channels are semi-closed or closed systems that are very different environments to open seawater, and may exhibit distinct biogeochemical cycling. Here, we investigate how trace metals behave during brine formation and subsequent dilution and biological uptake. We then discuss the implications of our results on the impact of sea ice melt on seawater nutrient distribution.

Our results show that $\mathrm{Cd}$ followed a simple trend for both 2005 and 2006 that, although there is scatter, behaved conservatively and falls approximately along the dilution curve of seawater from Marguerite Bay ( $\mathrm{Cd}$ vs salinity $r^{2}=0.86, n=21$; Fig. 5a). Hence, seawater and ice can be considered as a closed system with respect to $\mathrm{Cd}$, i.e. $\mathrm{Cd}$ in brine is sourced only from the seawater from which it froze, as opposed to atmospheric or meteoric input. Other field studies have shown that macronutrients only correlate with 
salinity in regions of low biological activity (Dieckmann et al. 1991). However, sea ice in Marguerite Bay is relatively productive with biomass, measured using the algal pigment $\operatorname{chl} a$, in sea ice brine ranging up to $8 \mathrm{mg} \mathrm{m}^{-3}$ in brine during winter (Fig. 4). This suggests that either biological uptake of $\mathrm{Cd}$ is negligible with respect to supply, or regeneration of micronutrients is rapid within the sea ice system.

Although there is scatter, sea ice brine exhibits a similar $\mathrm{Cd}$ and $\mathrm{PO}_{4}{ }^{3-}$ fractionation behaviour to open marine seawater (Fig. 5b). As for seawater, there was a positive relationship between $\mathrm{Cd}$ and $\mathrm{PO}_{4}{ }^{3-}$ in the brine samples $\left(r^{2}=0.75, n=19\right.$; Fig. 6). Compared to $\mathrm{Cd}, \mathrm{PO}_{4}{ }^{3-}$ concentrations are less well correlated with salinity $\left(r^{2}=0.62, n=20\right)$, which could be indicative of some biological uptake of $\mathrm{PO}_{4}{ }^{3-}$. This possible decoupling between $\mathrm{Cd}$ and $\mathrm{PO}_{4}{ }^{3-}$ could be responsible for the scatter in the $\mathrm{Cd}-\mathrm{PO}_{4}{ }^{3-}$ relationship. $\mathrm{Si}(\mathrm{OH})_{4}$ appears to behave more conservatively than $\mathrm{PO}_{4}{ }^{3-}\left(\mathrm{Si}(\mathrm{OH})_{4}\right.$ vs. salinity $r^{2}=0.85, n=20$; Fig. $5 \mathrm{c}$ ), which suggests that $\mathrm{Si}$ variations in sea ice are also driven mainly by physical processes, rather than diatom productivity.

There is a positive relationship between $\mathrm{Cd}$ and biomass (approximated by chl a) in sea ice brine, which further suggests $\mathrm{Cd}$ concentrations are not controlled primarily by biological uptake (Fig. 5d). Physical processes, such as brine rejection and dilution through melting are more likely to be the dominant controls on the distribution of $\mathrm{Cd}$ (and other metals) in sea ice. Despite this, there was variability in the relationship between chl $a$ concentration and micronutrients within a sea ice season, which could represent a biological signature (Fig. 5d). During the early sea ice season (July-September), there was a lower biomass supported for a given concentration of micronutrients compared to spring (November-December). This is consistent with greater demand for $\mathrm{Cd}$ in spring relative to early winter, for example due to higher carbonic anhydrase (Cd-CA) activity in spring relating to higher growth rates (due to warmer temperatures, higher irradiance and longer photoperiods) and $\mathrm{CO}_{2}$ availability from melting sea ice (Lane \& Morel 2000a, 2000b, Morel et al. 1994, Sunda \& Huntsman 2005). Further work establishing the relationship between other important trace metals, such as zinc, and $\mathrm{Cd}$ concentrations in sea ice brine may shed light on possible micronutrient limitation during winter. There may also be other factors limiting biomass accumulation in the early season, for example grazing pressure, light or temperature limitation.

The melting of sea ice is thought to promote productivity by 1) providing macro- and micronutrients and seeding for the phytoplankton blooms, and 2) changing water column stratification favouring net phytoplankton growth (Sedwick \& Di Tullio 1997). However, observations of natural communities show sea ice diatom assemblages are significantly different to open water assemblages, and sea ice algal cells released from ice can be in a "poor physiological state" (Scharek et al. 1994, Boyd et al. 1995). Further, the degree of stratification in the melt zone is highly dependent on prevailing wind conditions, local hydrographic conditions and degree of surface mixing (Savidge et al. 1995, Whitehouse et al. 1995, Suzuki et al. 2001).

Here, differences between the diatoms present in sea ice (filtered samples examined under SEM appear to be dominated by Fragilariopsis spp. and Navicula spp.) and seawater (dominated by Thalassosira spp. and Proboscia spp.) suggest spring sea ice melt does not seed the ice free water in Marguerite Bay. Furthermore, our nutrient data presented here suggest that, in this case, dilution is sufficiently significant such that sea ice melt may not have an impact on the bulk content of bioactive metals in coastal waters. However, the release of micronutrients may depend on the timing and extent of sea ice melt. Brine expulsion during the early sea ice season may release important dissolved micronutrients into the water. Later in winter, sea ice porosity increases as ice temperatures fall below $-5^{\circ} \mathrm{C}$ (air temperatures between -5 and $-9^{\circ} \mathrm{C}$; Golden et al. 1998, Perovich et al. 2004) allowing flushing of brine pockets and dilution through melting. Brine expulsion and biological uptake in persistent sea ice causes concentrations of metals in underlying seawater to exceed brine micronutrient concentrations, which may become limiting for some sea ice algae.

Observational records indicate that sea ice dynamics off the West Antarctic Peninsula are highly variable on a variety of timescales and may have retreated over recent decades (Cotte \& Guinet 2007, Clarke et al. 2008). Our results show that fundamentally different processes control nutrient distribution in seawater and sea ice, and the timing and rate of melting may be important in determining the release of nutrients from sea ice. This implies future changes in sea ice dynamics, and the timing of advance and retreat of sea ice relative to seasonal light levels, may impact nutrient distribution and Antarctic marine ecosystems.

\section{Summary}

Here, we present a method for the sampling and measurement of cadmium in sea ice brine from coastal Antarctica. This method shows minimal contamination and could be applied to a wide range of dissolved micronutrients or trace metals.

We show brine $\mathrm{Cd}$ concentrations follow a simple dilution curve consistent with a closed ice-seawater system, suggesting that micronutrients are sourced only from the parental seawater. $\mathrm{PO}_{4}{ }^{3-}$ exhibits a weaker relationship with salinity, which may be a result of biological uptake. In contrast, $\mathrm{Si}(\mathrm{OH})_{4}$ correlates well with salinity, suggesting $\mathrm{Si}(\mathrm{OH})_{4}$ variations are also controlled by physical processes rather than diatom productivity. The positive relationship between $\mathrm{Cd}$ and biomass indicates this dilution process is the primary control on the distribution of micronutrients in sea ice rather than biological uptake, 
even in a highly productive setting. There appears to be a more complex relationship between $\mathrm{Cd}$ concentrations and biomass, consistent with changing $\mathrm{Cd}$ requirements, or other limiting factors, throughout the year. Differences in the biological community between sea ice and seawater, and the low micronutrient concentrations in brine later in the sea ice season, suggest that spring melting of sea ice does not contribute significantly to the biomass or nutrient status of seawater. The fundamentally different processes influencing nutrients in seawater and sea ice signify future changes in sea ice dynamics and seasonality may impact nutrient distribution in Antarctic seawater.

\section{Acknowledgements}

The authors would like to acknowledge S. Ripperger for the use of the Cd spike, and J. Arden at the University of Oxford for assistance with Cd measurements by ICP-MS. Thanks also to A. Thomas (University of Oxford), A. Annett and R. Ganeshram (Edinburgh University) for assistance, useful discussion and insight. We would also like to thank A. Clarke (British Antarctic Survey) and the marine assistants P. Mann and H. Rossetti, for help in the field. Many thanks also to the base commander and other member of staff at Rothera Research Station. We would also like to thank the contribution of an anonymous reviewer, Martin Ellwood and the editor David Walton for help in improving the manuscript. The work was funded as part of NERC Antarctic Funding Initiative AFI4-02. KRH is funded by NERC grant NER/S/A/2004/12390.

\section{References}

Abelmann, A. \& Gersonde, R. 1991. Biosiliceous particle flux in the Southern Ocean. Marine Chemistry, 35, 503-536.

Abelmann, A., Gersonde, R., Cortese, G., Kuhn, G. \& Smetacek, V. 2006. Extensive phytoplankton blooms in the Atlantic sector of the glacial Southern Ocean. Paleoceanography, 21, 10.1029/2005PA001199.

Arrigo, K. \& Thomas, D.N. 2004. Large scale importance of sea ice biology in the Southern Ocean. Antarctic Science, 16, 471-486.

Boyd, P.W., Robinson, D., SAvidge, G. \& Williams, P.J.L. 1995. Water column and sea-ice primary production during austral spring in the Bellingshausen Sea. Deep-Sea Research II, 42, 1177-1200.

Brierley, A.S. \& Thomas, D.N. 2002. Ecology of Southern Ocean pack ice. Advances in Marine Biology, 43, 171-281.

Cadée, G.C., Gonzalez, H.E. \& Schnack-Schiel, S.B. 1992. Krill diet affects faecal string settling. Polar Biology, 12, 253-259.

Clarke, A., Meredith, M.P., Wallace, M.I., Brandon, M.A. \& Thomas, D.N. 2008. Seasonal and interannual variability in temperature, chlorophyll and macronutrients in Ryder Bay, northern Marguerite Bay, Antarctica. Deep-Sea Research II, 55, 18-19.

Clarke, D.B. \& Ackley, S.F. 1984. Sea ice structure and biological activity in the Antarctic marginal ice zone. Journal of Geophysical Research, C89, 2087-2095.

Cota, G.F. \& Sullivan, C.W. 1990. The photoadaptation, growth and production of bottom ice algae in the Antarctic. Journal of Phycology, 26, 399-411.

Cotte, C. \& Guinet, C. 2007. Historical whaling records reveal major regional retreat of Antarctic sea-ice. Deep-Sea Research I, 54, 243-252.
Cullen, J.T. 2006. On the nonlinear relationship between dissolved cadmium and phosphate in the modern global ocean: could chronic iron limitation of phytoplankton cause the kink? Limnology and Oceanography, 51, 1369-1380.

Cullen, J.T. \& Sherrell, R.M. 2005. Effects of dissolved carbon dioxide, zinc, and manganese on the cadmium to phosphorus ratio in natural phytoplankton assemblages. Limnology and Oceanography, 50, 1193-1204.

DE BAAR, H.J.W. 1994. Cadmium versus phosphate in the world ocean. Marine Chemistry, 46, 261-281.

Dieckmann, G.S., Arrigo, K. \& Sullivan, C.W. 1992. A high resolution sampler for nutrient and chlorophyll $a$ profiles of the sea ice platelet layer and underlying water column below fast ice in polar oceans. Marine Ecology Progress Series, 80, 291-300.

Dieckmann, G.S., Lange, M.A., Ackley, S.F. \& Jennings, J.C. 1991. The nutrient status in sea ice of the Weddell Sea during winter: effects of sea ice texture and algae. Polar Biology, 11, 449-456.

Elderfield, H. \& Rickaby, R. 2000. Oceanic Cd/P ratio and nutrient utilization in the glacial Southern Ocean. Nature, 405, 305-310.

Finkel, Z.V., Quigg, A.S., Chiampia, R.K., Schofield, O.E. \& Falkowski, P.G. 2007. Phylogenetic diversity in cadmium:phosphorus ratio regulation by marine phytoplankton. Limnology and Oceanography, 52, 1131-1138.

Golden, K.M., Ackley, S.F. \& Lytle, V.I. 1998. The percolation phase transition in sea ice. Science, 282, 2238-2241.

Hendry, K.R., Rickaby, R.E.M., Weston, K., De Hoog, J.C. \& RehKämPer, M. 2008. Cadmium and phosphate in coastal Antarctic seawater: implications for Southern Ocean nutrient cycling. Marine Chemistry, 112, 149-157.

KIRKWOOD, D.S. 1996. Nutrients: practical notes on their determination in seawater. Copenhagen: International Council for the Exploration of the Seas, ICES Techniques in Marine Environmental Sciences, no. 17, 23 pp.

KotTMEIER, S.T. \& Sullivan, C.W. 1990. Bacterial biomass and production in pack ice of Antarctic marginal ice edge zones. Deep-Sea Research, 37, 1311-1330.

LANe, T.W. \& Morel, F.M.M. 2000a. A biological function for cadmium in marine diatoms. PNAS, 97, 4627-4631.

Lane, T.W. \& Morel, F.M.M. 2000b. Regulation of carbonic anhydrase expression by zinc, cobalt and carbon dioxide in the marine diatom Thalassiosira weissflogii. Plant Physiology, 123, 345-352.

LizotTe, M.P. 2001. The contributions of sea ice algae to Antarctic marine productivity. American Zoologist, 41, 57-73.

McConville, M.J., Mitchell, C. \& Wetherbee, R. 1985. Patterns of carbon assimilation in microalgal community from annual sea ice, East Antarctica. Polar Biology, 4, 135-141.

McMinn, A., Skerrall, J., Trull, T., Ashworth, C. \& Lizotte, M.P. 1999. Nutrient stress gradient in the bottom $5 \mathrm{~cm}$ of fast ice, McMurdo Sound, Antarctica. Polar Biology, 21, 220-227.

Meredith, M.P., Brandon, M.A., Wallace, M.I., Clarke, A., Leng, M.J., Renfrew, I.A., van Lipzig, N.P.M. \& King, J.C. 2008. Variability in the freshwater balance of northern Marguerite Bay, Antarctic Peninsula: results from $\delta^{18} \mathrm{O}$. Deep-Sea Research, 55, 309-327.

Morel, F.M.M., Reinfelder, J.R., Roberts, S.B., Chamberland, C.P., Lee, J.G. \& YeE, D. 1994. Zinc and carbon co-limitation of marine phytoplankton. Nature, 369, 740-742.

Nelson, D.M. \& TrÉguer, P. 1992. Role of silicon as a limiting nutrient to Antarctic diatoms: evidence from kinetic studies in the Ross Sea iceedge zone. Marine Ecology Progress Series, 80, 255-264.

Nelson, D.M., Anderson, R.F., Barber, R.T., Brzezinksi, M.A., Buesseler, K.O., Chase, Z., Collier, R.W., Dickson, M.-L., Francois, R., Hiscock, M.R., Honjo, S., Marra, J., Martin, W.R., Sambrotto, R.N., SaYles, F.L. \& Sigman, D.E. 2002. Vertical budgets for organic carbon and biogenic silica in the Pacific sector of the Southern Ocean 1996-1998. Deep-Sea Research II, 49, 1645-1674. 
Parkinson, C.L. 2004. Southern Ocean sea ice and its wider linkages: insights revealed from models and observations. Antarctic Science, 16, 387-400.

Perovich, D.K., Elder, B.C., Claffey, K.J., Stammerjohn, S.E., Smith, R., Ackley, S.F., Krouse, H.R. \& Gow, A.J. 2004. Winter seaice properties in Marguerite Bay, Antarctica. Deep-Sea Research II, 51, 2023-2039.

RipPerger, S. \& RehKAmper, M. 2007. A highly sensitive MC-ICPMS method for $\mathrm{Cd} / \mathrm{Ca}$ analyses of foraminiferal tests. Journal of Analytical Atomic Spectrometry, 22, 1275-1283.

Ripperger, S., Rehkamper, M., Porcelli, D. \& Halliday, A.N. 2007. Cadmium isotope fractionation in seawater - a signature of biological activity. Earth and Planetary Science Letters, 261, 670-684.

Savidge, G., Harbour, D.S., Gilpin, L.C. \& Boyd, P.W. 1995. Phytoplankton distributions and production in the Bellingshausen Sea, austral spring 1992. Deep-Sea Research II, 42, 1201-1224.

Scharek, R., Smetacek, V., Fahrbach, E., Gordon, L.I., Rohardt, G. \& Moore, S. 1994. The transition from winter to early spring in the eastern Weddell Sea, Antarctica - plankton biomass and composition in relation to hydrography and nutrients. Deep-Sea Research I, 41, $1231-1250$

Sedwick, P.N. \& Di Tullio, G.R. 1997. Regulation of algal blooms in Antarctic shelf waters by the release of iron from melting sea ice. Geophysical Research Letters, 24, 2515-2518.

Shimmield, G.B., Ritchie, G.R. \& Fileman, T.W. 1995. The impact of marginal ice zone processes on the distribution of ${ }^{210} \mathrm{~Pb},{ }^{210} \mathrm{Po}$ and ${ }^{234} \mathrm{Th}$ and the implications for new production in the Bellingshausen Sea, Antarctica. Deep-Sea Research II, 42, 1313-1335.

Stapleford, L.S. \& Smith, R.E.H. 1996. The interative effects of temperature and silicon limitation on the psychrophilic ice diatom Pseudonitzschia seriata. Polar Biology, 16, 589-594.
Stephens, B.B. \& Keeling, R.F. 2000. The influence of Antarctic sea-ice on glacial-interglacial $\mathrm{CO}_{2}$ variations. Nature, 404, 171-174.

Sunda, W.G. \& Huntsman, S.A. 2005. Effect of $\mathrm{CO}_{2}$ supply and demand on zinc and growth limitation in a coastal diatom. Limnology and Oceanography, 50, 1181-1192.

Suzuki, H., SASAKI, H. \& FukUchi, M. 2001. Short-term variability in the flux of rapidly sinking particles in the Antarctic marginal ice zone. Polar Biology, 24, 697-705.

Thomas, D.N. \& Papadimitriou, S. 2003. Biogeochemistry of sea ice. In Thomas, D.N. \& Dieckmann, G.S., eds. Sea ice: an introduction to its physics, chemistry, biology and geology. Malden, MA: Blackwell, 267-294.

Thomas, D.N., Kennedy, H., Kattner, G., Gerdes, D., Gough, C. \& DiekmanN, G.S. 2001. Biogeochemistry of platelet ice: its influence on particle flux under fast ice in the Weddell Sea, Antarctica. Polar Biology, 24, 486-496.

Thomas, D.N., Lara, R.J., Haas, C., Schnack-Schiel, S.B., Diekmann, G.S., Kattner, G., Nothig, E. \& Mizdalski, E. 1998. Biological soup within decaying summer sea ice in the Amundsen Sea, Antarctica. Antarctic Research Series, 73, 161-172.

Weissenberger, J. 1992. The environmental conditions in the brine channels of Antarctic sea-ice. Reports on Polar Research, 111, 1-159.

Whitehouse, M.J., Priddle, J. \& Woodward, E.M.S. 1995. Spatial variability of inorganic nutrients in the marginal ice zone of the Bellingshausen Sea during the austral spring. Deep-Sea Research II, 42, $1047-1058$.

Wu, J. \& BoyLE, E.A. 1997. Low blank preconcentration technique for the determination of lead, copper, and cadmium in small-volume seawater samples by isotope dilution ICPMS. Analytical Chemistry, 69, 2464-2470.

Xu, Y., Feng, L., Jeffrey, P.D., Shi, Y. \& Morel, F.M.M. 2008. Structure and metal exchange in the cadmium carbonic anhydrase of marine diatoms. Nature, 452, 56-61. 